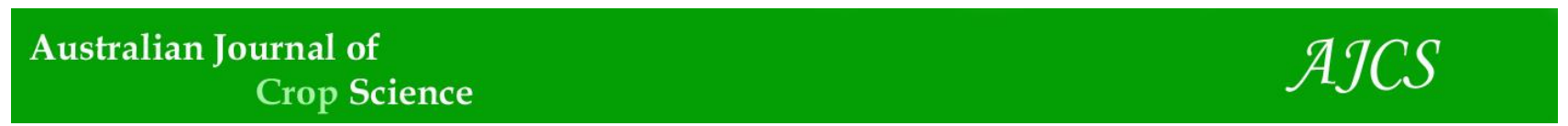

AJCS 14(07):1171-1179 (2020)

ISSN:1835-2707

doi: 10.21475/ajcs.20.14.07.p2483

\title{
Vegetative characteristics of soybean (Glycine max L.) as bioindicator parameter of herbicide in the soil
}

\author{
Maria Aparecida Peres-Oliveira ${ }^{1}$, Edna Maria Bonfim-Silva ${ }^{2}$, Tonny José Araújo da Silva ${ }^{2}$, Jefferson Vieira \\ José $^{2}$, Káritta Saldanha Martins ${ }^{2}$, Pedro Alberto Giovanne Engelberg ${ }^{1}$
}

\author{
${ }^{1}$ Federal University of Mato Grosso - UFMT, Institute of Exact and Natural Sciences, Department of \\ Biological Sciences, 5055 Students Avenue Rondonópolis, 78.735-901, Brazil \\ ${ }^{2}$ Federal University of Mato Grosso - UFMT, Institute of Agricultural and Technological Sciences, 5055 \\ Students Avenue Rondonópolis, 78.735-901, Brazil
}

Abstract

The objective of the present study was to evaluate the presence of the herbicide 2,4-D in the Neosol. We conducted the experiment in a greenhouse using the soybean crop as a bioindicator. A randomized block design with $5 \times 3$ factorial scheme composed of five application periods before sowing $(0,3,6,9$, and 12 days $)$ and three simulated rain $(0 \mathrm{~mm}, 20 \mathrm{~mm}$, and $30 \mathrm{~mm})$, with four repetitions was conducted. The herbicide dose was $1500 \mathrm{~g}$ a.i. ha ${ }^{-1}$, the rainfall was simulated one hour after pulverization. Twelve hours after the last rain simulation, CV. TMG ${ }^{\circledR}$ ANTA 82 RR was sown, and pot moisture remained at $80 \%$ of pot capacity throughout the experiment. Herbicide in the soil was evaluated by visual plant phyto-intoxication, plant height, shoot fresh mass and root fresh mass, and shoot dry mass and root dry mass at 26 days after sowing. Statistical analysis was performed according to the polynomial regression model. The application of herbicides in dry soils that remained without rain during the first hours resulted in greater residual effect on the soil $(0 \mathrm{~mm}$ of rain). The occurrence of higher humidity accelerated the degradation of the herbicide in the soil ( $30 \mathrm{~mm}$ of rain). Longer periods between application and sowing provided more significant increments. The herbicide's toxic effects reduced linearly as started from 12 days before sowing. The 2,4-D showed low persistence in the soil, and 12 days was observed to represent a safe time length between spraying and sowing, regardless of the occurrence of rainfall. The soybean was a good indicator of 2,4-D.

Keywords: Rain simulator; Residual effect; Phytointoxication; 2,4-D; Neosol.

Introduction

The total crop planted area in Brazil is about 78,853,498 hectares, of which soybean crop (Glycine max (L.)) occupies $35,726,751$, proving it a species with the largest extension of cultivation and relevant economic importance to the country (IBGE, 2019). The Midwest region stands out as the leading grain producer, with 26.584 million hectares of planted area (CONAB, 2019), 16.066 million of which are located in the state of Mato Grosso, which produces 67.215 thousand tons or $28 \%$ of the country's total crop production (IBGE, 2019). Among all the detrimental factors regarding agricultural production, the biotic elements can be cited as a major obstacle to productivity success. Weeds are one of the main components of the agroecosystem that directly interfere with the development and yield of several crops, and can therefore, lead the list of biotic factors that jeopardize production.

In many parts of the world, the development of agricultural production has always been related to the application of weed control herbicides, which are able to interfere with their physiology (Primel et al., 2005). However, the direct or indirect introduction of chemical compounds into the environment by humans results in environmental contamination. These compounds have a negative effect on the ecosystem balance, when misused, causing damage to the soil, and impair the health or humans and other living things (Jain et al., 2005). When present in excess in the soil, they can also cause economic losses in the succession of crops of interest, if they are sensitive to the molecule.

Pre-emergence herbicide application can be absorbed by weeds, cultivated plants, and the soil, which undergo processes such as leaching and degradation by chemical, physical, and biological activity (Filizola et al., 2002). In general, we can consider that performance of weed control is influenced by their ability to move in the soil (Firmino et al., 2008). This dynamic is governed by processes of retention, transformation, transportation, and their interactions (Spadotto et al., 2001).

According to Devine et al. (1983), temperature, relative humidity, and soil moisture interfere with herbicide behavior in the plant, also reflecting its control. When one of these variables is compromised, treatment may be unsatisfactory. Regarding humidity, control is affected by pre- or postemergence rainfall (Behrens and Elakkad, 1981; Bastiani et al., 2000, Carbonari et al., 2010). Factors such as the time interval between applications, the occurrence of rainfall (Anderson and Arnold, 1984), the amount and incidence of rain (Hammerton, 1967), as well as the different herbicides and types of formulations can effectively influence the efficiency of weed control. Thus, herbicides may have residual activities represented by their persistence in the 
environment which are influenced by the external interference (Dan et al., 2012).

2,4-Dichlorophenoxyacetic acid (2,4-D) is an important agrotoxin of the acidic herbicide class that is evidenced by its wide global utilization and has been used to control a variety of weeds. Because of its systemic nature and high selectivity, the herbicide is agglomerated in root growth tissues causing a development impediment, when absorbed by the plant (Amarante Junior et al., 2003). Little is known regarding herbicide behavior in the Brazilian soils due to the variability of the physical, chemical, and biological characteristics in Cerrado regions, which may present significant variability in composition. In this context, the objective of this study was to evaluate the interference of rainfall on the environmental behavior of the herbicide 2,4-D in Fluvic Neosol, using soybean crop as a bioindicator.

Results and discussion

\section{Overall phytointoxication}

During the phytointoxication evaluations, a significant difference was observed in the interactions between the application periods and the different blades of rain fall (Fig 1). All simulated rains $(0 \mathrm{~mm}, 20 \mathrm{~mm}$, and $30 \mathrm{~mm})$ exerted significant action throughout the periods (Fig 1A). In all treatments, $0 \mathrm{~mm}$ of rain provided higher phytointoxication scores. Regarding the periods, the linear behavior showed a decreasing trend in phytointoxication as sowing distanced from spraying (Fig 1B). This occurred in all blades of rain fall. Losses may occur due to the photodegradation process, in addition to other factors that may be involved, such as volatilization, which is accentuated by elevated soil surface temperature, chemical and biological degradation, and sorption, all of which should be considered to explain the disappearance of the herbicides in the soil (Silva et al., 2007).

The issue concerning the occurrence of rainfall has been studied by several authors, including the efficiency of weed control. Souza et al. (2012) observed that doses of the herbicide 2,4-D provided high percentages of intoxication to Myriophyllum aquaticum. Regardless of the dose, the herbicidal effect was reduced when rain occurred 15 minutes after its application.

While studying the effect of rain on the action of Imazapyr, Campos et al. (2010) observed that the rainfall $(10 \mathrm{~mm})$ that occurred in periods further apart from herbicide application reached control levels of up to $97.5 \%$. Such a result confirms the negative influence of early precipitation on herbicide persistence.

Historically, the influence of rain on herbicide efficiency is also related to the formulation. For example, 2,4-D amine, requires a much longer period without rain than 2,4-D ester to cause the same toxicity in several sensitive species (Behrens and Elakkad, 1981).

The highest values of plant intoxication were observed in periods 0 and 3 DBS (Fig 1A). Silva et al. (2011) found similar results with soybean plants. Phytointoxication was observed in all application periods at both tested doses, with higher values for 0 DBS.

According to Rodrigues and Almeida (2005), it is necessary to wait at least 10 days to sow soybeans after the application of 2,4-D in direct sowing, data that contribute to those found in the present study. The period of 12 DBS represented safety of sowing the crop in succession since the phytointoxication scores were the lowest observed in all of the studied periods.

In a study conducted in sorghum, Petter et al. (2011) also observed plant intoxication when 2,4-D was applied at presowing, although the effects disappeared 15 days after application.

According to Silva et al. (2011), the residual effect of 2,4-D on soybean emergence caused phytointoxication in all application periods at the two applied doses, presenting significant difference in relation to the control. The culture exhibited symptoms similar to those found by Constantin et al. (2007) for cotton and post-emergence application, which comprised leaf curling and petiole epinasty from three days after application (DAA), as well as yellowing and necrosis of flower buds from 14 DAA. At 5 and 10 DBS, 1005 g i.a. ha ${ }^{-1}$ of 2,4-D promoted a significant increase in plant injury.

\section{Plant height}

The plant height variable was significantly affected by the rainfall regimes and the periods between spraying and sowing (Fig 2). Only the $30 \mathrm{~mm}$ rain blades did not exert significant action on the plants (Fig 2A), whereas, in relation to the periods, only periods 6 and 9 DBS were not significant. The other periods exerted action on the plants (Fig 2B). There was an increase in plant height as sowing distanced apart from spraying, at which in 0 DBS period, the plants achieved lower growth. Similarly, even in the presence of the herbicide, a greater height was occurred at all application times as rainfall increased.

The absorption of herbicides is limited by the amount that penetrated the leaf cuticle, which is influenced by weed species, herbicide characteristics, and environmental conditions (Deuber, 1982). Thus, the loss of the herbicide or its activity also depends on the occurrence of rainfall (intensity and duration) in this interval, as well as the method and application technology, the plant species involved, and climatic conditions (Jakelaitis et al., 2001; Silva et al., 2007).

The most significant heights were related to the higher rainfall regime. Silva et al. (2007) observed that there must be a critical period for each herbicide without rainfall until a sufficient amount is absorbed by weed. Rainfall is important in the action of many herbicides since it has been shown to be a limiting factor in their control, provided greater rates of height.

Reis et al. (2010) reported lower heights with preemergence application, in shorter periods regarding the contact of the seed with the herbicide. According to the authors, the plants had contact with the product from the moment of germination, resulting in greater absorption. Silva et al. (2011) observed a reduction in height in soybean crops, even at a concentration of $1005 \mathrm{~g}$ i.a. ha ${ }^{-1}$ of 2,4-D, when compared to the control in all application periods. Such an outcome is due to the action of auxinic herbicides, which affect cell wall plasticity, thus, interfering with the activity of RNA polymerase, during the synthesis of nucleic acids and proteins. It also induces cell proliferation in tissues, promoting cell division and elongation in the new parts of the plants (Ferreira, 2005).

Degradation is caused by microbial metabolism. Some soil conditions may maximize this type of deterioration, such as heat, high organic matter content, and moisture (Johnson et al., 1995). In this case, the rain may influence the acceleration of herbicide degradation, that is, in the higher blades of rain fall, soon after spraying, degradation was 
more significant, allowing the plants to achieve better development.

\section{Shoot fresh mass}

The results regarding the shoot fresh mass of the soybean plants (Fig 3), considering rainfall ( $\mathrm{mm}$ ), show that there was a significant interaction, with a linear increase of fresh mass as soil moisture increased. Similar behavior was observed in relation to the periods. When the time length between spraying and sowing increased, there was an increment in shoot fresh mass (Fig 3A and 3B).

Among all the blades of rain fall, $0 \mathrm{~mm}$ was the one that provided the smallest increase in the weight of this variable (Fig 3A). The impact of the periods on shoot fresh mass showed that the distance between the date of application and sowing directly influenced the residual effect of the herbicide, providing a more significant increase when compared to the other treatments at 12 DBS, while obtaining smaller amounts of fresh mass near 0 DBS (Fig 3B). The availability of the herbicide may be favored in the presence of water. Thus, it is also subject to the interaction of factors inherent to its degradability, such as chemical or biological degradation. Episodes provided at higher rainfall intensities following spraying may provide greater soil moisture and further favor leaching, reducing the effectiveness period and intensifying the residual effect on the soil.

The critical period between post-emergence herbicide application and the occurrence of rainfall varies according to the type of formulation, the employed dose, the solubility of the product in water, the weed species, the conditions under which they develop, and the amount of rain (Anderson and Arnold, 1984; Pires, 2000).

Persistence studies, such as those conducted by Hammerton (1967), Anderson and Arnold (1984), Rodrigues (2005) and Silva (2011), demonstrated that the time gap between the application period and sowing directly affects the development and yield of crops. In some cases, the herbicide may also interfere in the crop germination phase (Silva, 2011).

\section{Root fresh mass}

In the root fresh mass evaluations (Fig 4), the interaction between the rainfall regimes and the periods was significant. The highest root fresh mass results were found at $30 \mathrm{~mm}$ of rainfall (Fig $4 \mathrm{~A}$ ). As for the periods, the root fresh mass also presented a statistically significant difference, with the highest results obtained in the 12 DBS period, and the lowest at 0 DBS (Fig 4B).

The root system was developed according to water availability. Ball et al. (1992) stated that the most significant root development occurs in the soil layers, whose water availability is more substantial. Severino et al. (2004) observed that 2,4-D presented interference in root elongation when applied more closely between sowing and spraying, a fact that may have occurred due to the hormonal action of the herbicide, provided that it does not intoxicate the crop.

Leaching in the soil profile is strongly influenced by the amount and timing of rainfall after the application of the product (Banks and Robinson, 1986). In addition to rainfall, colloid adsorption, soil water infiltration rate, intensity of herbicide leaching is strongly dependent on the physicochemical characteristics of the applied products, especially water solubility (Deuber, 1992). The herbicide 2,4$D$ is highly soluble in water, and accumulates in plant roots, interfering with root development. When applied near the sowing period, it accumulates in the roots, thus forming aerial roots and thickening the lateral root system. Its persistence in the soil occurs from 1 to 4 weeks in clay soil and predominantly hot climate present in the Brazilian Cerrado. These characteristics interfere in germination and plant development results. Similar increments using other cultures have been described by Junior (1998), Neto (2005), Silva et al. (2007) and Reis et al. (2010).

\section{Shoot dry mass}

The different blades of rain and the time interval between spraying and sowing had significant effects on shoot dry mass (Fig 5). The interaction between the factors regarding dry matter increment capacity (Fig 5A) showed higher values for plants that received $30 \mathrm{~mm}$ of rainfall. Likewise, the rain provided more significant degradation of the herbicide, favoring plant development. As for the application periods, the highest increment was reached at 12 DBS (Fig 5B). Therefore, as the time of application approached the day of sowing, the achieved decrease in dry mass was greater, regardless of the rainfall regime. The most significant reductions were at 0 and 3 DBS.

The interference of rain has been present regarding the action of several herbicides. In some cases, the dry mass of herbicide-applied plants is lower than in non-applied plants, with a reduction of $40 \%$ to $60 \%$, as the soil water potential decreases (Pereira et al., 2010). The largest reductions are generally observed in treatments, where no rain occurs compared to plants that receive rain 15 minutes after application (Souza et al., 2013).

Regarding the interactions of the analyzed treatments in the present study, the factors, periods, and rainfall intensity $(\mathrm{mm})$ significantly interfered with the shoot dry mass results, corroborating studies such as those conducted by Silva et al. (2011) and Inácio (2016).

Similar effects were observed by Silva et al. (2011) and Peres-Oliveira et al. (2016), where, in both studies, the 0 DBS period presented the lowest results of shoot dry mass at different herbicide doses for soybean plants, and the closer the period between application and sowing, the lower the results obtained.

In a study with Picloram + 2,4-D in corn, D'Antonino et al. (2009) observed a $13.6 \%$ inhibition rate in dry mass accumulation when compared to the control. Petter et al. (2011) reported the smallest reductions in sorghum plant dry matter accumulation using 2,4-D pre-sowing applications.

The residual effect of herbicides applied to soybeans may result in impairment of subsequent crops, as has been shown in sunflowers. Studies have shown that the herbicides diclosulam and imazethapyr promoted significant reductions ( $42.16 \%$ and $16.05 \%$, respectively) in the shoot dry matter accumulation of sunflower sown 115 days after herbicide application on soybean crop (Dan et al., 2012).

The reduced mass accumulation found in the present study may reflect the phytotoxic effect of the herbicide and the reduction in plant height since plants intoxicated with the herbicide 2,4-D present lower metabolic activity, given the 
Table 1. Chemical and granulometric characterization of Neosol at the $0.0-0.20 \mathrm{~m}$ layer of depth.

\begin{tabular}{|c|c|c|c|c|c|c|c|c|c|c|c|c|c|c|c|c|}
\hline $\begin{array}{l}\text { Layer } \\
(\mathrm{cm})\end{array}$ & $\mathrm{pH}$ & $\mathrm{Ca}$ & Mg & Al & $\mathrm{H}$ & СТC & M.O & $P$ & $\mathrm{~K}$ & $\mathrm{Zn}$ & $\mathrm{Cu}$ & $\mathrm{Fe}$ & $\mathrm{Mn}$ & B & $S$ & V \\
\hline & $\mathrm{CaCl}_{2}$ & \multicolumn{5}{|c|}{----cmolc dm ${ }^{-3}$} & $\mathrm{~g} \mathrm{dm}^{-3}$ & \multicolumn{8}{|c|}{ 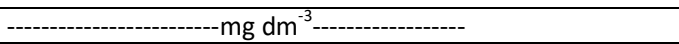 } & $\%$ \\
\hline $0.0-0.2$ & 4.1 & 0.2 & 0.2 & 0.8 & 3 & 4.2 & 12.3 & 1.1 & 12 & 0.7 & 0.3 & 128 & 3.6 & 0.49 & 7.1 & 10.4 \\
\hline
\end{tabular}

A)

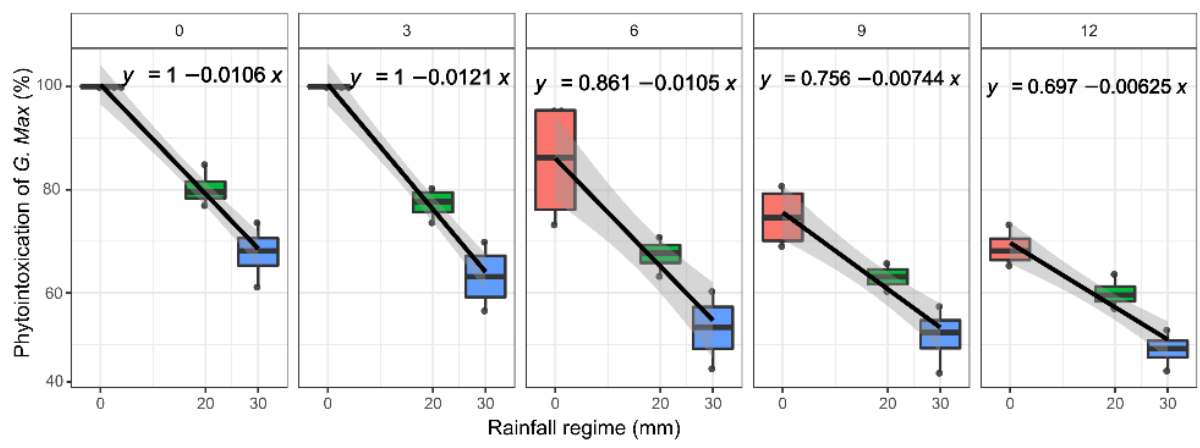

B)

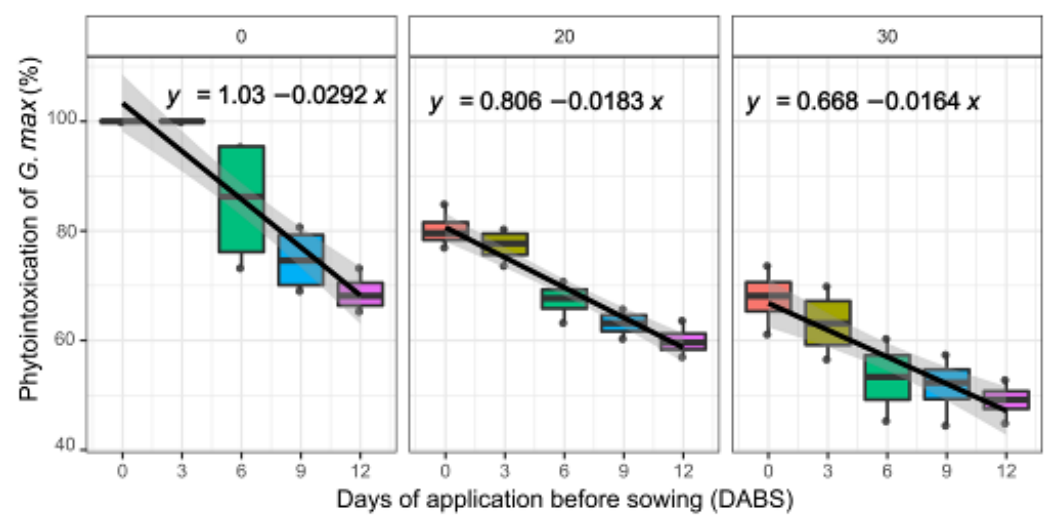

Fig 1. Percentage of phytointoxication in soybean plants (Glycine max (L.)). Interaction between the periods and the different amounts of simulated rainfall (A) and action of the blades of rain throughout the periods before sowing (B).

A)

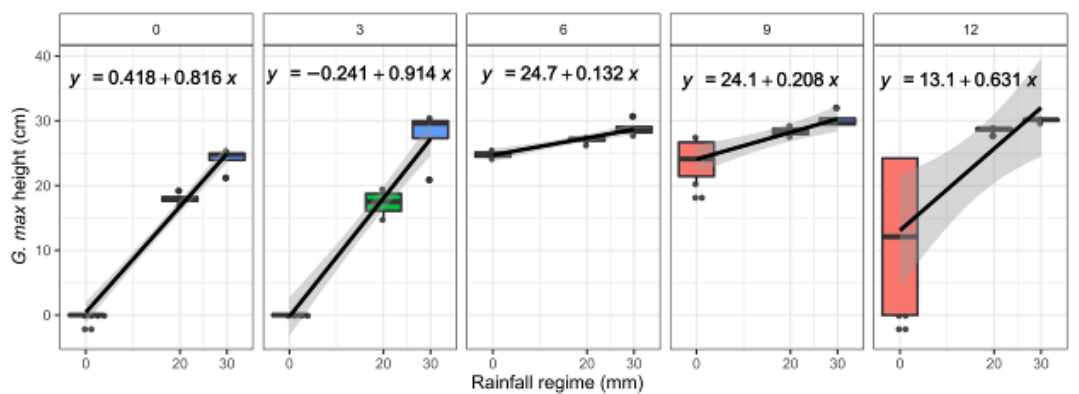

B)

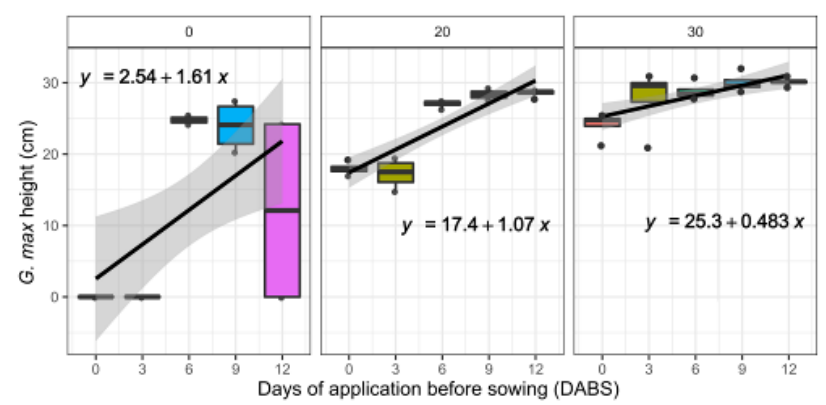

Fig 2. Height $(\mathrm{cm})$ of soybean plants (Glycine max (L.)). Interaction between the periods and the different amounts of simulated rainfall $(A)$ and action of the blades of rain throughout the periods before sowing (B). 
A)

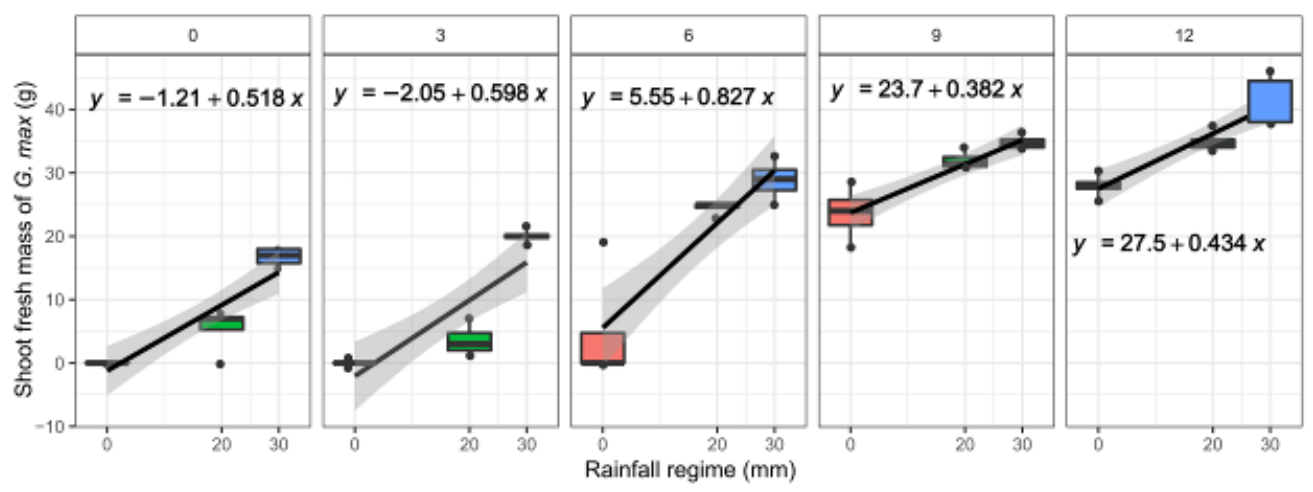

B)

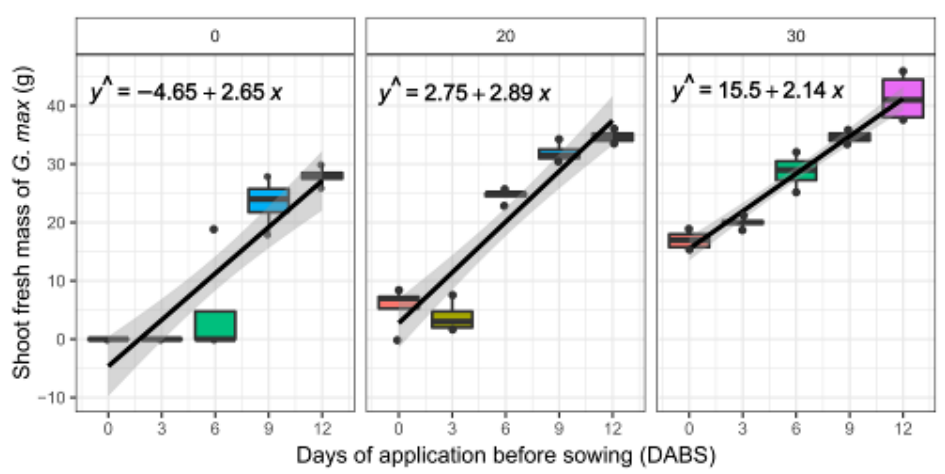

Fig 3. Shoot fresh mass (SFM, g) of soybean plants (Glycine $\max (\mathrm{L}$.)). Interaction between the periods and the different amounts of simulated rainfall (A) and action of the blades of rain throughout the periods before sowing (B).

A)

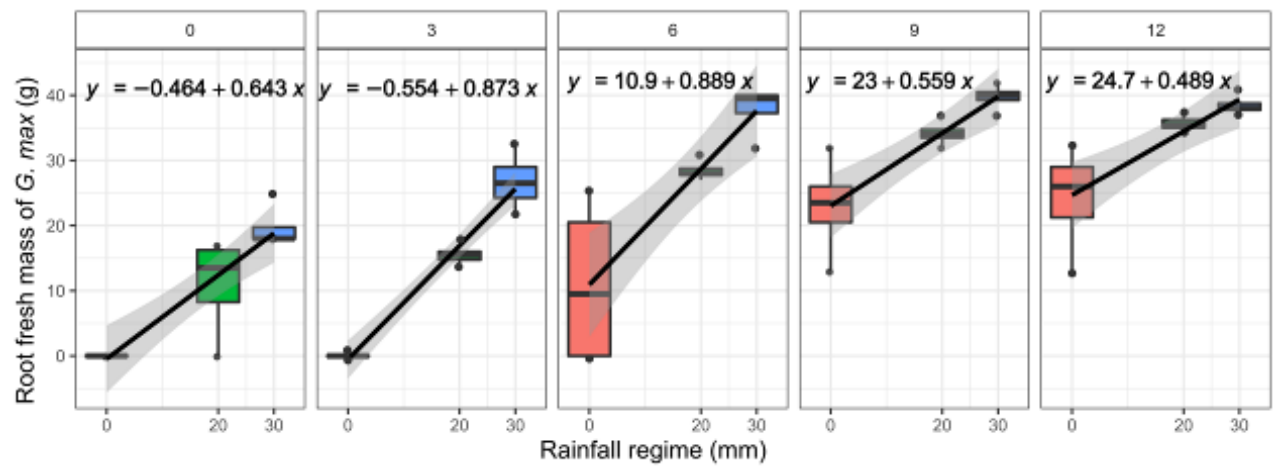

B)

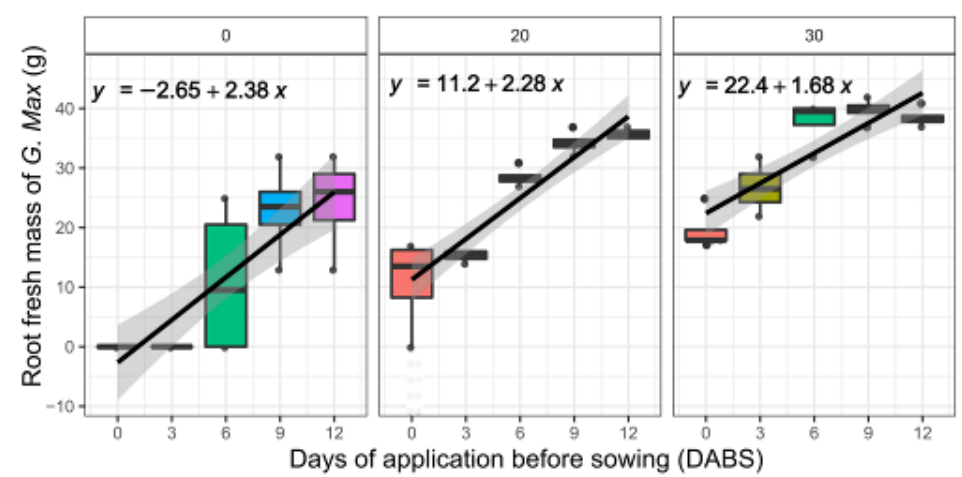

Fig 4. Root fresh mass (RFM, g) of soybean plants (Glycine max (L.)). Interaction between the periods and the different amounts of simulated rainfall $(A)$ and action of the blades of rain throughout the periods before sowing $(B)$. 
A)

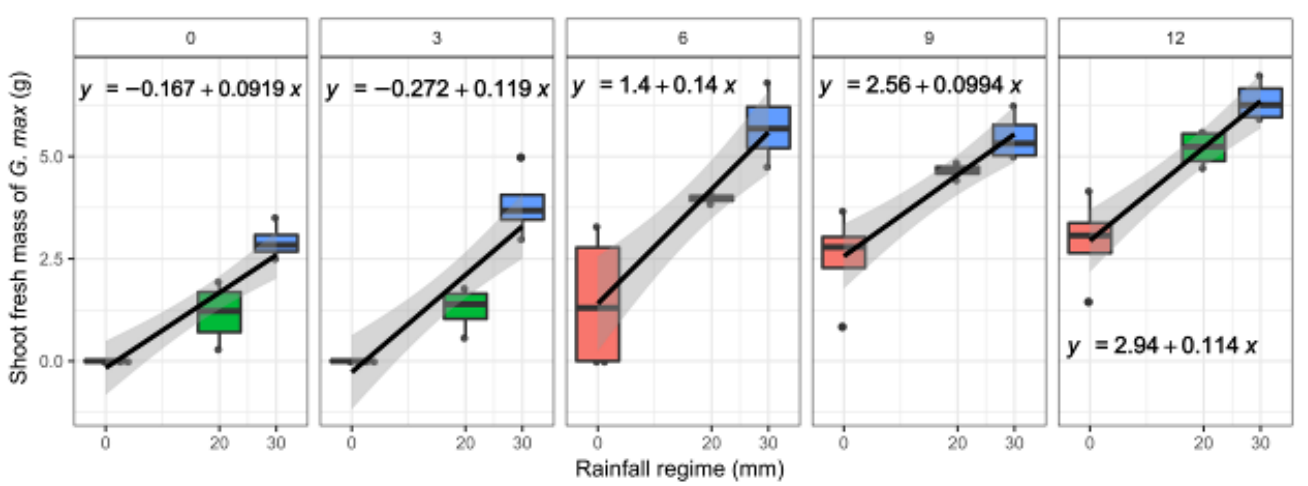

B)

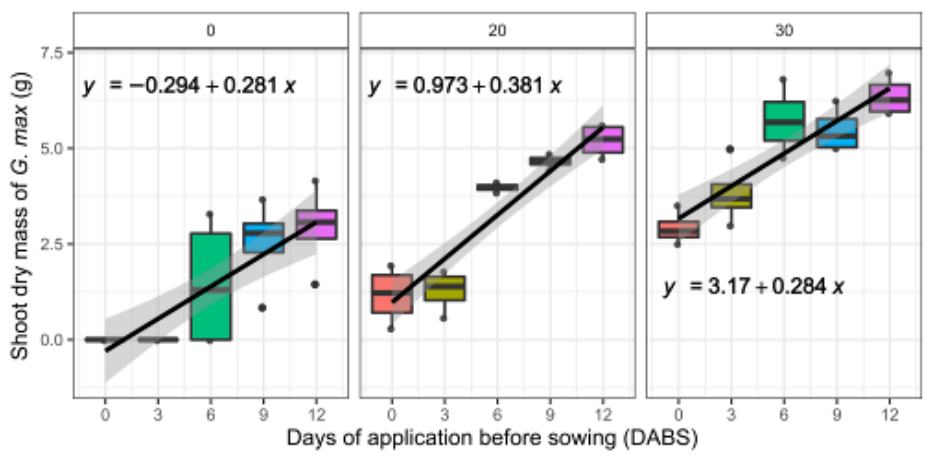

Fig 5. Shoot dry mass (SDM, g) of soybean plants (Glycine max (L.)). Interaction between the periods and the different amounts of simulated rainfall $(A)$ and action of the blades of rain throughout the periods before sowing $(B)$.

A)

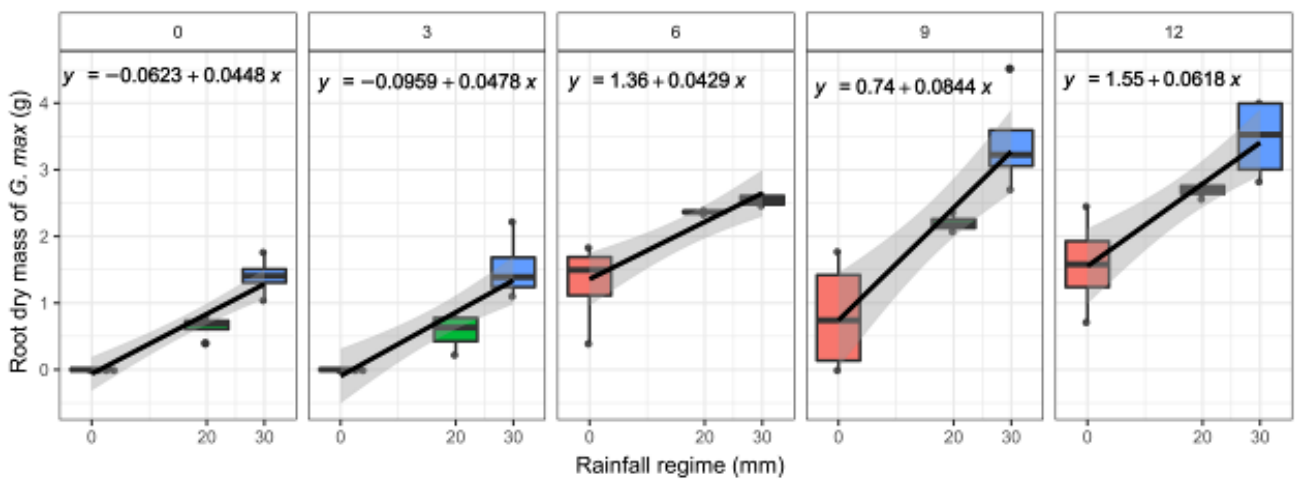

B)

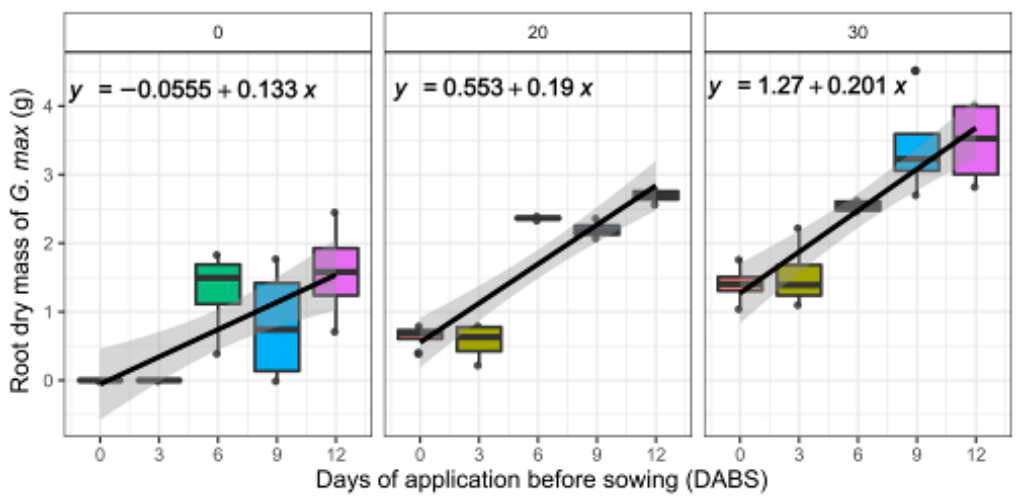

Fig 6. Shoot dry mass (SDM, g) of soybean plants (Glycine max (L.)). Interaction between the periods and the different amounts of simulated rainfall $(A)$ and action of the blades of rain throughout the periods before sowing (B). 
entire metabolism of the plants is affected by the herbicide (Petter et al., 2011).

\section{Root dry mass}

Root dry mass was also significantly affected by the interaction between the blades of rain and the periods (Fig 6). The most substantial increase was in $30 \mathrm{~mm}$ of rainfall, contrasting with $0 \mathrm{~mm}$ (Fig 6A). The highest results were obtained in the 12 DBS period, and the lowest at 0 DBS, as shown in Fig 6B. The application time, closer to the day of sowing has caused reduction of dry mass. Such a fact can be justified by the higher concentration of herbicide in the soil at sowing and also the interference that soil moisture exerts on its presence. Reis et al. (2010) also observed the action of soil moisture regarding interference in the dry mass of plants. The authors obtained greater increments in root dry mass in soils with higher moisture content when analyzing treatments in pre- and post-emergence corn crop. Bastiani et al. (2000) applied herbicides for weed control and observed that in $30 \mathrm{~mm}$ of rainfall, there was no difference between the compounds considering the variable dry mass. Silva et al. (2017), evaluated the persistence of 2,4-D in Latosol and observed that the weight of the root dry mass was influenced by the time interval between sowing and herbicide spraying. This fact can be explained by the action of 2,4-D, which has a deleterious effect on bioindicator plants, leading to a decrease in dry mass due to its presence in the soil. The effect of pre-emergence 2,4-D phytotoxicity in the 0 DBS period may cause a reduction in root dry mass, among other symptoms, when compared to post-emergence application at 21 DAA, even in crops such as corn (Reis et al., 2010). 2,4-D can also be lost through volatilization. Volatilization rates are determined by the temperature and molecular shape of the herbicide on the soil surface, where it is primarily determined by soil pH (McCall et al., 1981). In general, dry soils will present less loss by volatilization (Que Hee and Sutherland, 1981). The absence of rainfall in the first hour may decrease herbicide loss, thus impairing plant development at $0 \mathrm{~mm}$ of rain. Souza (2011), evaluated rainfall intervals on herbicide efficiency and found that 2,4-D rendered higher amounts of dry mass in plants subjected to longer time intervals between application and rainfall, reducing dry mass accumulation as the rainless period increased. Herbicides such as glyphosate and 2,4-D amine require a minimum rainless period after application of 4 hours in order to avoid hampering weed control (Oliveira Junior et al., 2011). According to Oliveira Junior et al. (2011), it is known that only three herbicides can penetrate the plasma membrane through carrier-mediated processes: Paraquat, Glyphosate, and 2,4-D. Donaldson et al. (1973) demonstrated that the absorption of 2,4-D in barley roots is dependent on the metabolic energy supply. Under the conditions in which the experiment was carried out, the action of 2,4-D on dry mass constituted a short residual period since the results showed linear behavior, allowing the largest increments to occur close to 12 DBS.

\section{Materials and methods}

\section{Experimental design and seeding}

The present study was conducted under controlled greenhouse conditions, Soil and Biodiversity Laboratory of the Cerrado Studies and Research Center (NUPEC), at the Federal University of Mato Grosso, in the municipality of
Rondonópolis (latitude 1628"15' South and longitude $54038^{\prime \prime} 08^{\prime}$ West, at an altitude of $284 \mathrm{~m}$ ). The utilized growth substrate consisted of Fluvic Neosol (Embrapa, 2013), which was dried in the shade for a period of $24 \mathrm{~h}$. Afterward, it was sieved with a $4 \mathrm{~mm}$ mesh and submitted to chemical and particle size analysis (Table 1 ), according to the methodology used by Embrapa (2017). According to the results and the crop demands, liming and fertilization of micro- and macronutrients were carried out, complying with the respective periods to provide optimal plant development. After this process, the soil was sprayed, and the soybean seed was sown. Each experimental unit was composed of $5 \mathrm{dm}^{3}$ pots of soil containing eight Cv.TMG ANTA 82 RR soybean seeds (Glycine max L.), which were sown at a depth of $5 \mathrm{~cm}$. The soil was maintained at $80 \%$ moisture in the pot capacity during the experiment, according to the methodology proposed by Bonfim-Silva et al. (2011), as of the first spraying.

The experimental design was in randomized blocks, composed of a $5 \times 3$ factorial scheme, with five application periods before sowing $(0,3,6,9$, and 12 days) and three blades of simulated rain $(0 \mathrm{~mm}, 20 \mathrm{~mm}$, and $30 \mathrm{~mm})$, with four repetitions.

\section{Sprayer and rain simulation}

The dose of the herbicide 2,4-D was constant (1500 g.a. ha $\left.{ }^{1}\right)$. The herbicide spray was carried out at 6:00 am, velocity are of $2 \mathrm{~km} / \mathrm{h}$, a relative humidity a $60 \%$ and temperature of 24 degrees Celsius. A precision costal spray (CO2) was used, with $2 \mathrm{~m}$ application bar and four spray nozzle $50 \mathrm{~cm}$ spaced, in which the compression chamber actuated manually. A Sprayer nozzle was XR 110024 with spray consumption to $200 \mathrm{~L} \mathrm{ha}^{-1}$. One hour after each spraying, rainfall was simulated using a $3 \mathrm{~m} \times 3 \mathrm{~m}$ rainfall simulator device made of aluminum rods with a rectangular profile (Bonfim-Silva et al., 2019). The fan opening angle was 80, operating at a working pressure of 5 to $500 \mathrm{PSI}$, a flow rate of 18.92 to 132.47 L min ${ }^{-1}$, and an opening diameter of 0.243 ".

\section{Evaluations parameters}

Twelve hours after the last rain simulation in period 0 , two furrows were made in the soil, followed by soybean sowing in all the pots. Herbicide persistence in the soil was assessed by visual plant phytointoxication (SBCPD, 1995), with scores of $0-100 \%$ every 4 days for a period of 26 days, plant height $(\mathrm{cm})$, shoot fresh mass - SFM (g) and root fresh mass - RFM (g), and shoot dry mass - SDM (g) and root dry mass - RDM (g) at 26 days after sowing.

The experimental data were subjected to analysis of variance $(P \leq 0.05)$, and the results were compared by regression analysis of quantitative variables $(P \leq 0.05)$. In the data analysis, the free $R$ Statistical $3.4 .4^{\oplus}$ software ( $R$ Core Team, 2019) was used. Parametric statistical analysis was implemented using functions available in the expdes.pt (Ferreira; Cavalcanti and Nogueira, 2018) and ggpmisc (Aphalo, 2016) packages. The construction of the graphs was conducted using the ggplot2 package (Wickham et al., 2018).

\section{Conclusion}

The application of herbicides in dry soils that remained without rain during the first hours resulted in greater residual effect on the soil ( $0 \mathrm{~mm}$ of rain). The plants that received the largest blades of rain stood out above the 
others, in all evaluated parameters. The occurrence of higher humidity accelerated the degradation of the herbicide in the soil (30 $\mathrm{mm}$ of rain). Longer periods between application and sowing provided more significant increments. The herbicide showed decreased toxic effects linearly in the soil as the experiment approached 12 days after sowing. 2,4-D has a short soil duration. Twelve days after sowing a safe time interval between spraying and sowing can occur, regardless of the occurrence of rainfall.

\section{References}

Amarante Junior OP, Santos TCR, Nunes GS (2003) breve revisão de métodos de determinação de resíduos do herbicida ácido 2, 4-diclorofenoxiacético (2, 4-D). Química Nova. 26 (2): 223-229.

Anderson D, Arnold WE (1984) Weed control in sunflowers (Helianthus annus) with desmediphan and phenmediphan. Weed Sci. 32: 310-314.

Aphalo PJ (2016) Learn R ...as you learnt your mother tongue Leanpub. Available from: https://leanpub.com/learnr

BALL DA (1992) Weed seed bank response to tillage, herbicides, and crop rotation sequence. Weed Science, Champaign, 40(4):654-659

Banks PA, Robinson EL (1986) Soil reception and activity of acetochlor, alachlor and metolachlor as affected by wheat (Triticum aestivum) straw irrigation. Weed Sci. 34: 607611.

Bastiani MLR, Silva AA, Ferreira FA, Cardoso CA (2000) Influência de chuva simulada após aplicação de herbicidas em pós- emergência, sobre o controle de plantas daninhas, em solo com dois níveis de umidade. Planta Daninha. 18 (1): 57-29.

Behrens R, Elakkad MA (1981) Influence of rainfall on the phytotoxicity of foliarly applied 2,4-D. Weed Sci. 29: 349355.

Bonfim-Silva EM, Silva TJA, Cabral CEA, Kroth BE, Rezende, D (2011) Desenvolvimento inicial de gramíneas submetidas ao estresse hídrico. Rev Caatinga. 24 (2).

Bonfim-Silva EM, Silva TJA, Souza ARD, José JV (2019) Use of software for image analysis and calibration of automated rain simulator. Int J Plant Soil Sci. 27 (5): 1-8.

Carbonari CA, Gomes GLGC, Velini ED (2010) Efeitos de períodos sem a ocorrência de chuva na eficácia do flumioxazin aplicado no solo e na palha de cana-de-açúcar. Rev Bras Herbicidas. 9 (3): 81-88.

Companhia Nacional de Abastecimento - CONAB. Levantamento julho2019 - Safra 2018/2019 - Grãos. (2019). Available from: <https://www.conab.gov.br/infoagro/safras $>$ Accessed on Aug 06.

Constantin J, Oliveira Junior RS, Fagliari JR, Pagliari PH, Arantes JGZ, Cavalieri SD, Framesqui, VP, Gonçalves DA (2007) Efeito de subdoses de 2,4-D na produtividade do algodão e suscetibilidade da cultura em função de seu estádio de desenvolvimento. Eng Agríc Jaboticabal. 27: 2429.

D'Antonino L, Silva AA, Ferreira LR, Cecon PR, Quirino ALS, Freitas LHL (2009) Efeito de culturas na persistência de herbicidas auxínicos no solo. Planta Daninha. Viçosa-MG, 27 (2): 371-378.

Dan HA, Dan LGM, Barroso ALL, Procópio SO, Oliveira Júnior RS, Braz PGB, Alonso DG (2012) Atividade residual de herbicidas usados na soja sobre o girassol cultivado em sucessão. Ciência Rural. 42 (11).

Campos CF, Souza GSF, Pereira MRR, Martins D (2010) Efeito da chuva sobre a ação do herbicida imazapyr no controle de plantas daninhas aquáticas. Irriga Botucatu. 15 (2): $151-$ 158.

Deuber R (1982) Controle de plantas daninhas na cultura da soja. In: FUNDAÇÃo CARGIL. A soja no Brasil Central. 2.ed. Campinas. p. 367-392.

Deuber R (1992) Ciência das plantas daninhas: fundamentos. Jaboticabal: FUNEP. 1: $431 \mathrm{p}$.

Devine M, Bandeen JD, Mckersie BD (1983) Temperature effects on glyphosate absorption, translocation, and distribution in quackgrass (Agropyron repens). Weed Science. 461-464.

Donaldson TW, Bayer DE, Leonard OA (1973) Absorption off 2,4-dichlorophenoxyacetic acid and 3-(p-chlorophenyl)1,1-dimethylurea (monuron) by barley roots. Plant Physiol. 52: 638-645.

Embrapa Santos HG (2013) Sistema brasileiro de classificação de solos $-3^{\circ}$ ed. rev. ampl. - Brasília, DF: Embrapa. 353.

EMBRAPA (2017) Manual de métodos de análise de solo. Teixeira PC, Donagemma GK, Fontana A, Teixeira WG, editores técnicos. - 3. ed. rev. e ampl. - Brasília, DF : Embrapa, 2017.

Ferreira EB, Cavalcanti PP, Nogueira DA (2013) Exp Des.pt: Experimental Designs package (Portuguese). R package version 1.1.2.

Ferreira FA, Silva AA, Ferreira LR (2005) Mecanismos de ação de herbicidas. $V$ Congresso Brasileiro de Algodão. Universidade Federal de Viçosa: MG, 2005. Available from: $<$ https://www.cnpa.embrapa.br/produtos/algodao/public acoes/trabalhos_cba5/336.pdf>. Accessed on: 03/27/2019.

Filizola HF, Ferreira VL, Sans LMA, Gomes MAF, Ferreira CJA (2002) Monitoramento e avaliação do risco de contaminação por pesticidas em água superficial e subterrânea na região de Guairá. Pesq Agropec Bras. 37 (5): 659-667.

Firmino LE, Tuffi Santos LD, Ferreira LR, Ferreira FA, Quirino ALS (2008) Movimento do herbicida imazapyr no perfil de solos tropicais. Planta Daninha. 26 (1): 223-230.

Hammerton JL (1967) Environmental factors and susceptibility to herbicides. Weeds. 330-336.

Inácio EM (2016) Impactos da deriva do herbicida 2,4-D em culturas sensíveis. 2016. Thesis (Doctorate in Phytotechny) - Luiz de Queiroz Superior School of Agriculture, University of São Paulo, Piracicaba, 2016.

Instituto Brasileiro de Geografia e Estatística - IBGE (2019) Levantamento Sistemático da Produção agrícola. Available from: <https://sidra.ibge.gov.br/tabela/1618> Accessed on: Aug 06, 2019.

Jain R, Kapur M, Labana S, Lal B, Sarma P, Bhattacharya D, Thakur I (2005) Microbial diversity: Application of microorganisms for the biodegradation of xenobiotics. Current Science. 89(1):101-112.

Jakelaitis A, Ferreira LR, Silva AA, Miranda G (2001) Controle de digitaria horizontalis pelos herbicidas glyphosate, sulfosate e glifosate potássico submetidos a diferentes intervalos de chuva após a aplicação. Planta Daninha, Viçosa-MG. 19 (2): 279-285.

Johnson WG, Lavy TL, Gbur EE (1995) Sorption, mobility, and degradation of triclopyr and 2,4-D and four soils. Weed Sci. 43: 678-684.

Junior TGC (1998) Efeitos da aplicação de herbicidas em préplantio no estabelecimento de pastagens de verão e inverno, em semeadura direta. 2008, 99 pp. Dissertation (Masters in Science, Área de Concentração Produção 
Vegetal) - Graduate Program in Agronomy, Federal University of Paraná, 1998.

Mccall PJ, Vrona SA, Kelley SS (1981) Fate of uniformly carbon-14 ring labeled 2,4,5-Trichlorophenoxyacetic acid and 2,4-Dichlorophenoxyacetic acid. J Agric Food Chem. 29: 100-107.

Neto CFO, Costa RCL (2005) Efeito do 2,4-D no alongamento de raízes e epicótilos de pepino (Cucumis sativus). Rev. Ciências agrarias. Belém. 43:.77-81.

Oliveira Junior RS, Constantin J, Inoue MH (2011) Biologia e manejo de plantas daninhas. Curitiba, PR: Omnipax, 2011. $348 p$

Pereira MRR (2010) Efeito de herbicidas sobre plantas de Brachiaria plantaginea submetidas a estresse hídrico. Planta Daninha, Viçosa. 28: 1047-1058.

Peres-Oliveira MA, Bonfim-Silva EM, Silva VM, Vieira ECS (2016) Persistence of 2, 4-D and glyphosate in a Cerrado soil, Brazil. Af J Agric Res. 11 (11):912-919.

Petter FA, Pacheco LP, Alcantara NF, Zuffo AM, Procópio SO, Almeida FA (2011) Desempenho agronômico do sorgo em função de doses e épocas de aplicação do herbicida 2,4D. Planta Daninha, Viçosa. 29: 1091-1098.

Pires NM, Ferreira FA, Silva AA, Cardoso AA, Oliveira VR (2000) Quantificação dos herbicidas glyphosate e sulfosate na água após simulação de chuva. Planta Daninha. 18 (3): 491-499.

Primel EG, Zanella R, Kurz MHS, Gonçalves FF, Machado SO, Marchezan E (2005) Poluição das águas por herbicidas utilizados no cultivo do arroz irrigado na região central do estado do Rio Grande do Sul, Brasil: predição teórica e monitoramento. Quimica Nova. 28 (4): 605-609.

Que Hee SS, Sutherland RG (1981) The Phenoxyalkanoic Herbicides, Volume I: Chemistry, Analysis, and Environmental Pollution. CRC Press, Inc., Boca Raton, Florida. 319 p.

R Core Team (2019) R: A language and environment for statistical computing. $\mathrm{R}$ Foundation for Statistical Computing, Vienna, Austria. URL https://www.Rproject.org/.
Reis, TC, Santos TS, Andrade AP, Neves AF (2010) Efeitos de fitotoxidade do herbicida 2,4-D no milho em aplicações pré e pós-emergência. Rev. Biol Ciências da Terra, Paraíba. 10 (1): 25-33.

Rodrigues BN, Almeida FS (2005) Guia de herbicidas. $5^{a}$ edição. Londrina: Grarfmake. 592.

Severino LS, Silva MIL, Beltrão NEM, Cardoso GD (2004) Sintomas de fitotoxicidade causada pelo herbicida 2,4-D em plântulas de mamoneira. Rer Brasi Oleaginosas e Fibrosas. 8 (1): 785-787.

Silva FML, Cavalieri SD, São José AR, Ulloa SM, Velini ED (2011) Atividade residual de 2,4-D sobre a emergência de soja em solos com texturas distintas. Rev Bras Herb São Paulo. 10 (1):29-36.

Silva JF, Ferreira LR, Ferreira FA (2007) Herbicidas: absorção, translocação, metabolismo, formulação e misturas. In: Antônio Alberto da Silva, José Francisco da Silva. Tópicos em manejo de plantas daninhas. 1 ed. Viçosa: Ed. UFV. 1: 149-188.

Silva VM (2017) Soja como bioindicador para o estudo do potencial de lixiviação do 2,4-d em Latossolo com chuva simulada. 2017, 103 pp. Dissertation (Masters in Tropical Agriculture) - Graduate Program in Agronomy, Cuiabá, 2017.

Souza GSF (2011) Intervalos de chuva na eficiência de herbicidas aplicados em pós-emergência. 2011, 82 pp. Dissertation (Masters) - São Paulo State University, School of Agronomic Sciences, Botucatu.

Souza GSF, Pereira MRR, Vitorino HS, Campos CF, Martins D (2012) Influência da chuva na eficácia do herbicida 2,4-D no controle de Myriophyllum aquaticum. Planta Daninha Viçosa. 30 (2): 263-267.

Souza GSF, Pereira MRR, Martins D (2013) Efeito da chuva na eficiência de herbicidas aplicados em pós-emergência sobre corda-de-viola. Planta Daninha Viçosa. 31 (1): 175184

Spadotto CA, Filizola HF, Gomes MAF (2001) Avaliação do potencial de lixiviação de pesticidas em Latossolo da região de Guaíra, SP. Rev. Ecotoxicologia Meio Ambiente. 11: 127-136.

Wickham H (2009) ggplot2: Elegant Graphics for Data Analysis. Springer-Verlag New York. 